\title{
Botrychium simplex E. Hitchc. (Ophioglossaceae) - a new species for the native flora of Ukraine
}

\author{
Ivan Yu. Parnikoza ${ }^{1 *} \&$ Zbigniew Celka ${ }^{2}$
}

${ }^{1}$ Institute of Molecular Biology and Genetics NAS of Ukraine, Zabolotnoho 150, 03680 Kyiv, Ukraine

${ }^{2}$ Department of Plant Taxonomy, Faculty of Biology, Adam Mickiewicz University in Poznań, Umultowska 89, 61-614 Poznań, Poland

* corresponding author (e-mail: ivan.parnikoza@gmail.com)

\begin{abstract}
The work presents the results of herbarium survey that resulted in finding Botrychium simplex E. Hitchc. - a new for the native Ukrainian flora species of the family Ophioglossaceae. A specimen of this taxon was found in the National Herbarium of Ukraine in the M. G. Kholodny Institute of Botany of National Academy of Sciences of Ukraine in Kyiv (KW) among the specimens of Botrychium lunaria (L.) Sw. originating from the surroundings of Kharkiv. Thus, this finding indicates the most south-eastern locality of $B$. simplex in Europe found so far.
\end{abstract}

Key words: least moonwort, common moonwort, rare species, Ukraine, herbarium, Kyiv, KW

\section{Introduction}

The genus Botrychium Sw. is represented in the world flora by 25 species (Mabberley 2008), while in Europe by seven (Valentine \& Moore 2007). The majority of European species of Botrychium belong to threatened taxa on the scale of whole Europe (e.g., Blitz et al. 2011), individual countries, e.g.: Belarus (Paszkov et al. 2005), Poland (Zarzycki \& Szeląg 2006; Kaźmierczakowa et al. 2014), Lithuania (Rašomavičius 2007), Ukraine (Didukh 2009), and Germany (Ludwig \& Schnittler 1996; floraweb.de), or regions, e.g.: Wielkopolska (Jackowiak et al. 2007), Kaliningrad oblast (Dedkov \& Griszanov 2010), Dnipropetrovska oblast (Travlieiev 2010), Pskovskaya oblast (Istomin et al. 2014), Podkarpacie (Oklejewicz et al. 2015), and Novgorodskaya oblast (Vetkin et al. 2015).

In Ukraine, four species of Botrychium were found thus far: B. lunaria (L.) Sw., B. matricariifolium (Retz.) A. Braun ex W. D. J. Koch, B. multifidum (S. G. Gmel.) Rupr. i B. virginianum (L.). Sw. (Mosyakin \& Fedoronchuk 1999; Didukh 2000; Parnikoza 2010; Vasheka \& Bezsmertna 2012). They all belong to threatened taxa in Ukrainian flora (e.g., Didukh 2009; Parnikoza $\&$ Celka 2016). Because of this, studies of different aspects of biology and chorology of Botrychium, and even more widely, the species of Ophioglossaceae, have been conducted in Ukraine for over 10 years (see Parnikoza 2002, 2010; Chorney et al. 2004; Parnikoza \& Tsukanova 2005; Melnik 2009, Bezsmertna \& Heluta 2013; Votkalchuk et al. 2014; Parnikoza \& Celka 2016). The aim of this work is to provide information on Botrychium simplex, a species not previously identified and listed in the native flora of Ukraine.

\section{Material and methods}

In the genus Botrychium, similarly like in many other genera, some gaps or mistakes in species identifications may occur. In case of Botrychium simplex, misidentification with $B$. lunaria may happen, especially, in the vegetative phase. The distinct differences appear in the spore production phase, when the sporophore part is developed: in B. simplex - the sporophore part branches off the trophophore part below the half length of leaf, while in B. lunaria - in the middle or above the leaf (Fig. 1). These traits were taken into account in the studies of Ophioglossaceae species in all more important Ukrainian herbaria. In total, nearly 200 herbarium specimens of B. lunaria and 400 of other species of this genus were studied in the following herbaria: Yu. Fedkovych Chernivtsi State University (CHER), V. N. Karazin National University (CWU), Donetsk Botanical Garden of the National Academy of Sciences of Ukraine (DNZ), 


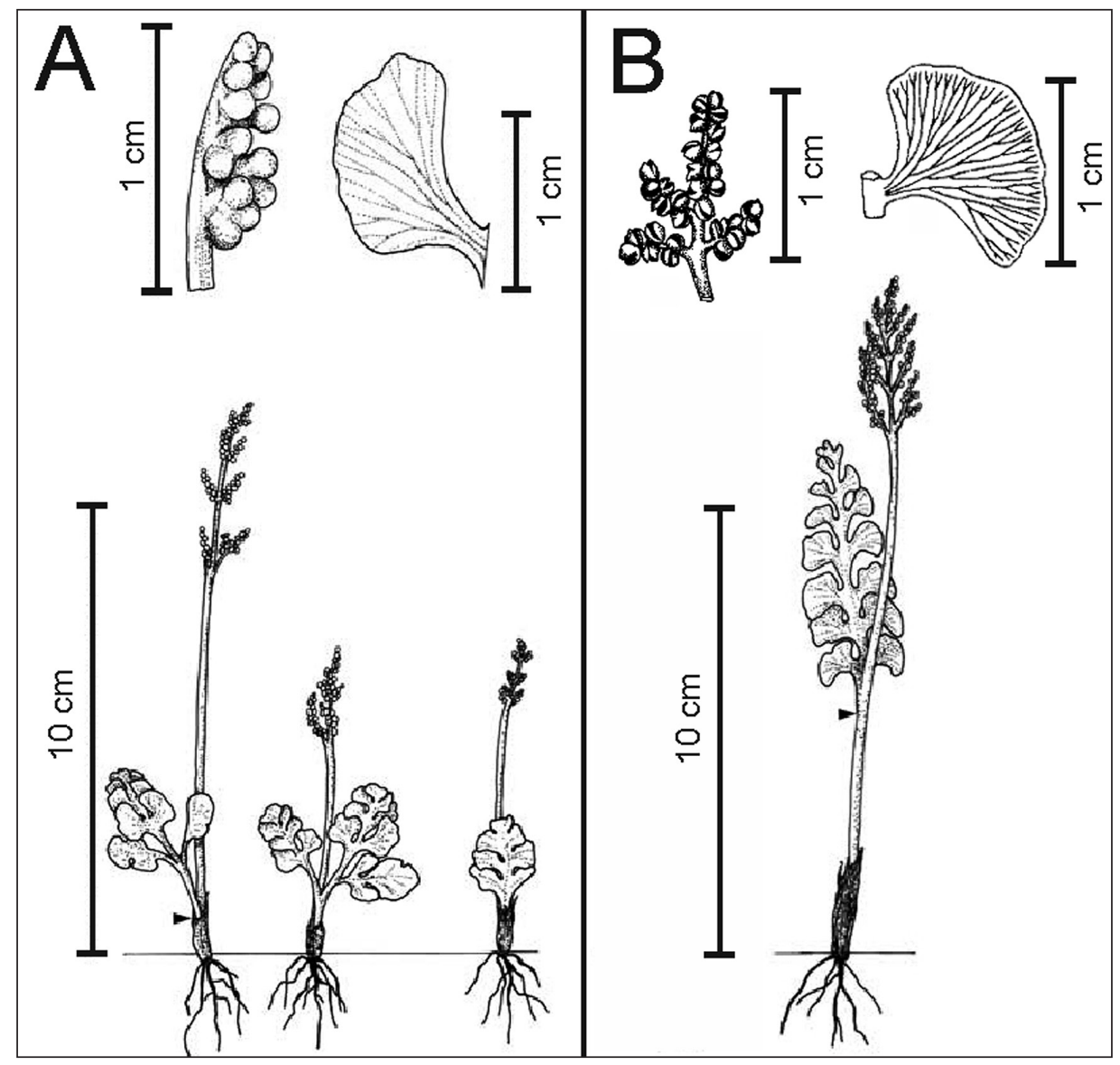

Fig. 1. The comparison of Botrychium simplex (A) and B. lunaria (B) according to Żukowski (2004, modified)

National Herbarium of Ukraine in the M. G. Kholodny Institute of Botany of National Academy of Sciences of Ukraine in Kyiv (KW), Ukrainian National Academy of Sciences in Kyiv (KWHA), O. V. Fomin Botanical Garden of Taras Schevchenko National University of Kyiv (KWHU), M. M. Gryshko National Botanical Garden in Kyiv (KWU), Ivan Franko National University of Lviv (LW), Institute of Ecology of the Carpathians in Lviv (LWKS), Museum of Natural History in Lviv (LWS), I. I. Mechnikov State University of Odessa (MSUD) and The State Nikita Botanical Gardens in Yalta (YALT).

\section{Results}

A herbarium specimen identified as $B$. lunaria, but corresponding to the traits of $B$. simplex var. simplex (Fig. 1) was found in the National Herbarium of Ukraine in the M. G. Kholodny Institute of Botany of National Academy of Sciences of Ukraine in Kyiv (KW). B. simplex has not been reported from Ukraine so far.

The specimen of $B$. simplex found in the Kyiv herbarium originates from the surroundings of Kharkiv (Fig. 2). It was collected on 12 June 1828 and identified by Vasyl M. Chernaiev, an Ukrainian botanist living in the years 1794-1871, who studied the flora of Kharkiv surroundings and expanded the herbarium collection. A preserved specimen of $B$. simplex is in the reproductive stage and has both the sporophore and trophophore part. The size of plant is $9 \mathrm{~cm}$. A specimen label contains the following information: legit: Chernaiev, teste: G. Shyrayev, locality: moist sandy sites in the community with Juncus ericetorum Pollich (currently Juncus capitatus Weigel) on the Kharkiv river. According to information available to the authors, the locality of $B$. simplex in the vicinity of Kharkiv probably no longer exists. This site was completely transformed due to human activities.

\section{Discussion}

Botrychium simplex occurs in three varieties: var. simplex, var. compositum (Lasch) Milde and var. tenebrosum (A. A. Eaton) R. T. Clausen (Anderson 2006; Farrar 2006, 2011). B. simplex var. tenebrosum is sometimes raised to the rank of species $-B$. tenebrosum A. A. Eaton (np. Anderson 2006; Farrar 2011). Among the neighbouring countries of Ukraine, B. simplex occurs in Poland (Żukowski et al. 2014), Belarus (Parfienov 2009) and Russia (Bobrov 1974; Tzvelov 2000). In Poland, only B. simplex var. simplex 

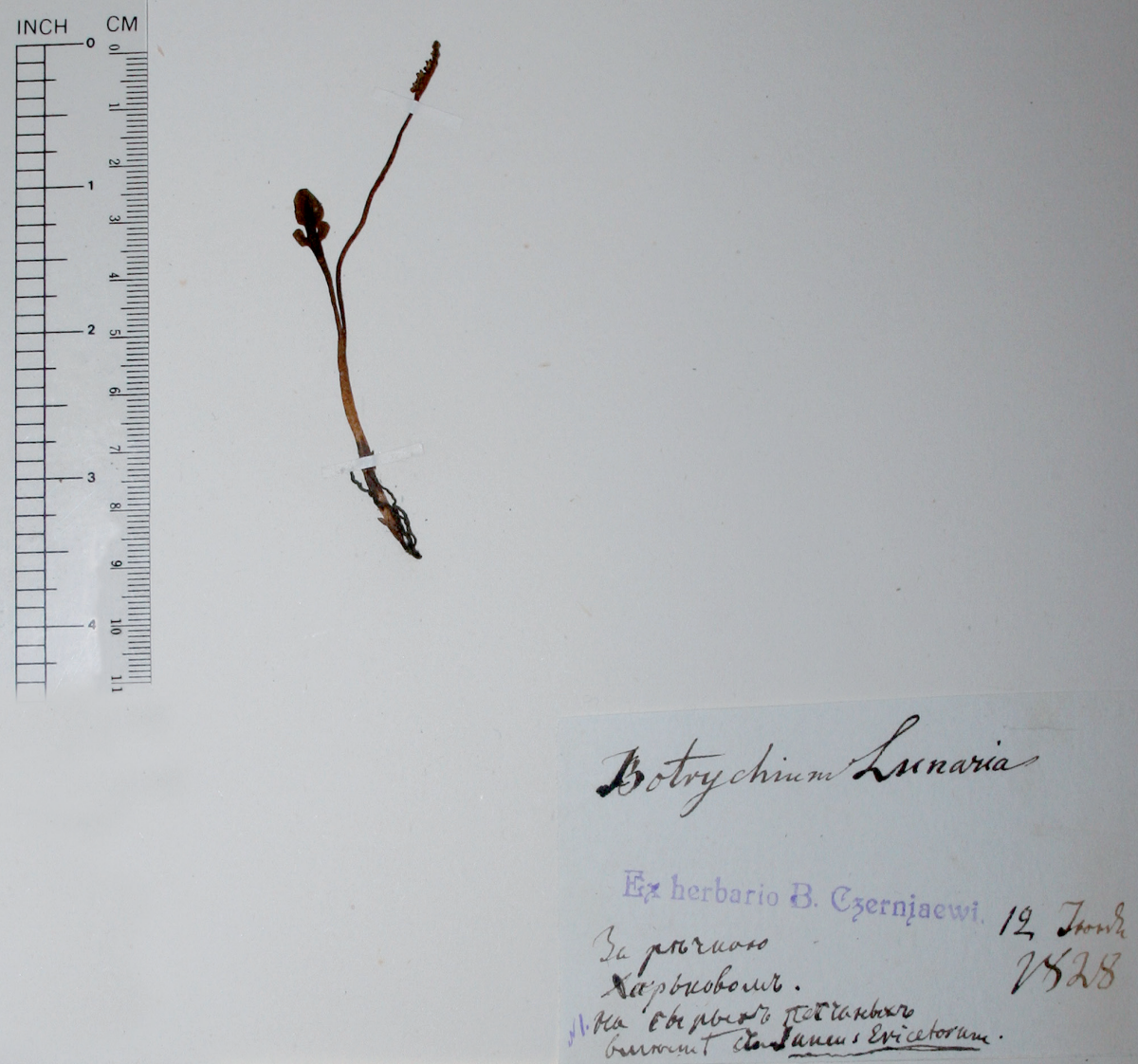

\section{Plantae vasculares rossicae}

Flora Charkoviensis

Gen. \& Sp.
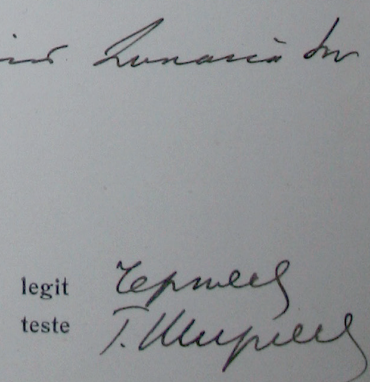

Fig. 2. Herbarium voucher of Botrychium simplex E. Hitchc. from the National Herbarium of Ukraine in the M. G. Kholodny Institute of Botany of National Academy of Sciences of Ukraine in Kyiv (KW)

was reported (Żukowski et al. 2014); in case of other countries, varieties were not specified.

B. simplex is a circumboreal-oceanic species (Zając $\&$ Zajacc 2009). It occurs in Europe, North America and Japan (Meusel et al. 1965; Hultén \& Fries 1986). In Europe it is one of rarest species of the genus Botrychium (Jalas \& Suominen 1972), found in the scattered locali- ties from Scandinavia to Corsica and from France to Belarus (Hultén \& Fries 1986). A disjunct locality in the vicinity of Kharkiv is the most south-east location of the species in the European part of its range (Fig. 3 ). The nearest localities of $B$. simplex were recorded in Belarus - south of Minsk (Parfienov 2009), and in Poland - Pakość in the Iłża Foothills (Żukowski et al. 


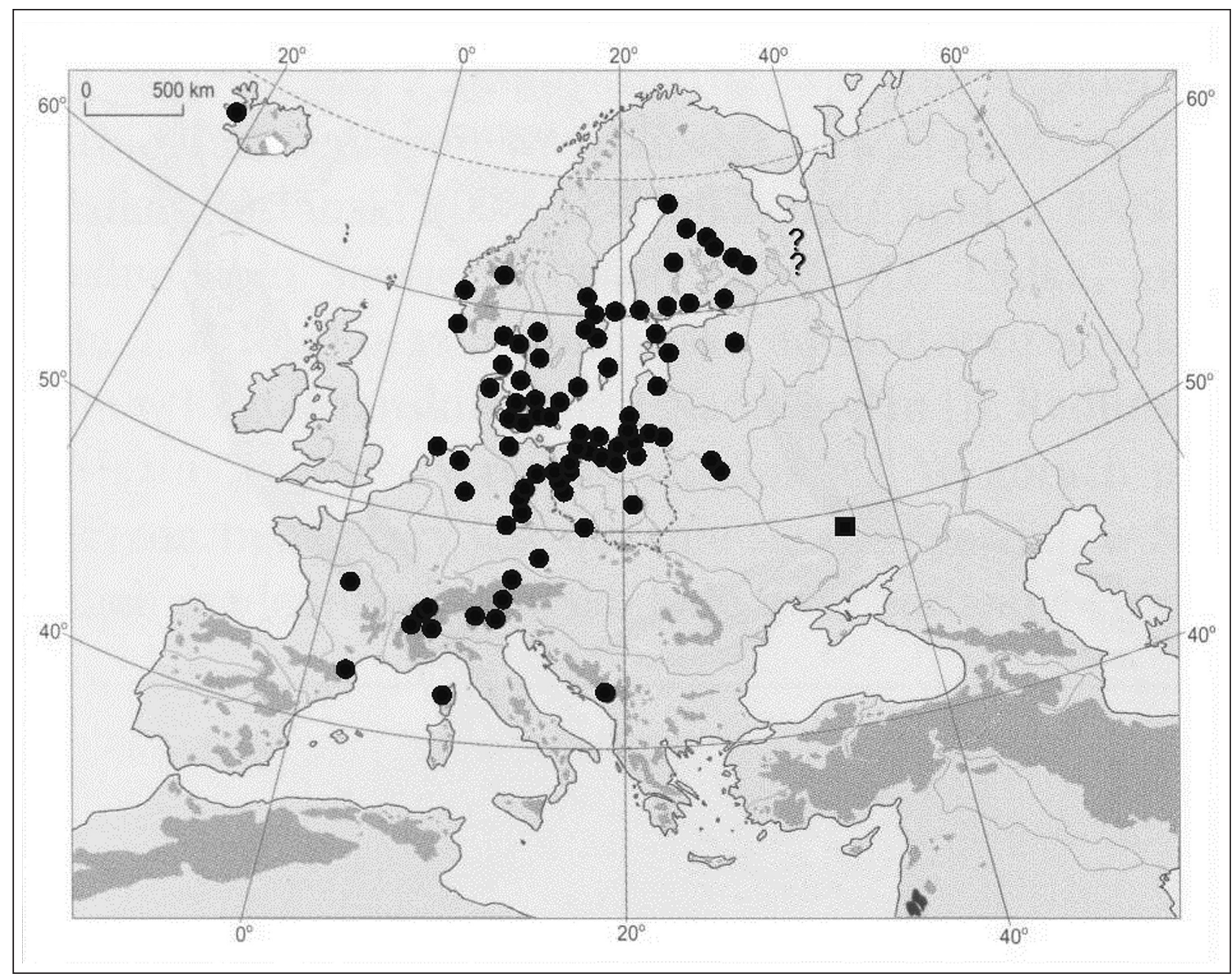

Fig. 3. Distribution of Botrychium simplex in Europe (after Żukowski et al. 2014, modified).

Explanations: - a new locality in the vicinity of Kharkiv, - other European localities, ? - uncertain localities

2014). In Belarus, there are 2 localities - one of them was observed for the last time in 2006 (M. Dzhus, pers. comm. 2014). In Poland, the data on 25 localities of $B$. simplex were collected so far. Most recently, the species was noted in the Pomerania region, near Lipnica and Wierzchowo, in the $80^{\text {th }}$ of the $20^{\text {th }}$ century. Despite many searches in the recent years, it has not been observed in Poland since then. In Russia, B. simplex was reported from the Pskov and St. Petersburg Oblasts (Tzvelov 2000).

In the European Union, B. simplex is classified as a Near Threatened (NT) species (Bilz et al. 2011). In individual countries of Central and Eastern Europe it is recognized as a highly threatened or extinct taxon. In Czech Republic and Poland, the species is listed as extinct (Grulich 2012; Żukowski et al. 2014), while in Belarus (Paszkov et al. 2005), Lithuania (Rašomavičius 2007), Germany (Ludwig \& Schnittler 1996; floraweb. de) and Russia (Dedkov \& Griszanov 2010; Istomin et al. 2014) it is considered a threatened taxon.

$B$. simplex is reported mostly from acidic, noncalcareous habitats. It is a constituent of Nardus grasslands and heaths (e.g., Dostál 1984; Chrtková 1988; Bennert et al. 2014; Żukowski et al. 2014). In Belarus, the species occurs in dry and peaty meadows (M. Dzhus pers. comm. 2014; Parfienov 2009), while in North America - in dry fields, marshes, bogs, swamps and along roadside ditches (Wagner \& Wagner 1993; Anderson 2006).

Finding this rare, on the European scale, species in the Ukrainian herbarium collection provides the basis for searching in the field. Field observations of the species' preferred habitats are essential. These habitats should be preserved and, if possible, protected. B. simplex should also be listed in the Ukrainian Red Data Book in the category not defined - an Ukrainian analogue of Data Deficient (DD) category of IUCN, because further studies may result in finding this species in herbarium collections and, maybe, in the field.

Acknowledgements. The authors thank to Dr. D. R. Farrar for checking the specimen identification, Dr. M. V. Shevera and Dr. Yu. Gamulia for the help in reading the specimen label and Prof. W. Żukowski, Prof. M. Dzhus and Prof. M. Aronsson for a helpful discussion. 


\section{References}

Anderson D. G. 2006. Botrychium simplex E. Hitchcock (little grapefern): a technical conservation assessment. [Online]. USDA Forest Service, Rocky Mountain Region. Available: http://www.fs.usda.gov/Internet /FSE_DOCUMENTS/stelprdb5206970.pdf [02.08.2016].

Bennert W. H., Sonneborn I. \& Horn K. 2014. Die Einfache Mondraute (Botrychium simplex, Ophioglossaceae) in Deutschland. Tuexenia 34: 205-232. doi: $10.14471 / 2014.34 .003$

Bezsmertna O. O. \& Heluta V. P. 2013. Distribution of Botrychium multifidum (Ophioglossaceae) in Ukraine. Ukr. Bot. J. 70(6) 792-795.

Blitz M., Kell S. P., Maxted N. \& Lansdown R. V. 2011. European Red List of Vascular Plants. 142 pp. Luxembourg, Publications Office of the European Union.

Bobrov A. E. 1974. Ophioglossaceae. In: An. A. Fedorov (ed.). Flora Partis Europaeae URSS, 1, pp. 68-72. Leningrad, Nauka.

Chorney I. I., Budgak V. V., Tokaruk A. I. \& Nykyrsa T. D. 2004.Genera Botrychium Sw. (Ophioglossaceae) in Bukovina flora - chorological characteristics. Scientific herald of Chernovtsy University, Collection of scientific works 194(Biology): 132-137.

Chrtková A. 1988. Ophioglossaceae Agardh. In: S. HeJnÝ \& B. Slavík (eds.). Květena České Socialistické Republiky, 1, 223-228 pp. Academia, Praha.

Council Directive 1992. Council Directive 92/43/EEC of 21 May 1992 on the conservation of natural habitats and of wild fauna and flora. Official Journal of the European Communities. No L 206: 7-50.

Dedkov V. P. \& GRishanov G. V. 2010. Krasnaya kniga Kaliningradskoĭ oblasti. 333 pp. Izdatel`stvo RGU im. I. Kanta, Kaliningrad.

Didukh YA. P. (ed.). 2000. Ecoflora of Ukraine, 1, 284 pp. Phytosociocentre, Kyiv.

Didukh YA. P. (ed.). 2009. Red data book of Ukraine. Vegetable kingdom. 912 pp. Globalconsalting, Kyiv.

Dostál J. 1984. Ophioglossaceae. In: H. J. Conert, U. Hamann, W. Schultze-Motel \& G. Wagenitz (eds.). Gustav Hegi Flora von Mitteleuropa, 1 (Pteridophyta), pp. 84-98. 3th ed. Verlag Paul Parey, Berlin-Hamburg.

FARRAR D. R. 2006. Systematics of moonworts Botrychium subgenus Botrychium. [Online]. http://www.public. iastate.edu/ herbarium/botrychium/Moonwort-Syste matics-June-06.pdf [26.08.2016].

FARRAR D. R. 2011. Systematics and Taxonomy of Genus Botrychium. [Online]. http://www.herbarium. iastate.edu/botrychium/Moonwort-Systematics.pdf [26.08.2016].

Grulich V. 2012. Red List of vascular plants of the Czech Republic: 3rd edition. Preslia 84: 631-645.

http://www.floraweb.de/pflanzenarten/rotelisten.html http://sweetgum.nybg.org/science/ih/

Hultén E. \& Fries M. 1986. Atlas of North European vascular plants. North of the Tropic of Cancer. I-III. xvi+1172 pp. Koeltz Scientific Books, Königstein.
Istomin A. V., Musatov V. Yu. \& Mozhzhina T. É. 2014. Krasnaya kniga Pskovskoĭ oblasti. 544 pp. Pskovskoĭ Gosudarstvennyĭ Universitet, Pskov.

Jackowiak B., Celka Z., Chmiel J., Latowski K. \& Żukowski W. Red list of vascular flora of Wielkopolska (Poland). Biodiv. Res. Conserv. 5-8: 95-127.

Jalas J. \& Suominen J. (eds.). 1972. Altas Florae Europaeae. Distribution of Vascular Plants in Europe. 1, Pteridophyta (Psilotaceae to Azollaceae), $121 \mathrm{pp}$. The Committee for Mapping the Flora of Europe \& Societas Biologica Fennica Vanamo, Helsinki.

Kaźmierczakowa R., Zarzycki K. \& Mirek Z. (eds.). 2014. Polish Red Data Book of Plants. Pteridophytes and flowering plants. 895 pp. Polska Akademia Nauk, Instytut Ochrony Przyrody, Kraków.

Ludwig G. \& Schnittler M. 1996. Rote Liste der Pflanzen Deutschlands. [Online]. https:/www.bfn.de/ fileadmin/MDB/documents/RoteListePflanzen.pdf [26.08.2016].

MabBerley D. J. 2008. Mabberley`s Plant-book. A Portable dictionary of plants, their classification and uses. 3th ed. 1021 pp. Cambridge, Cambridge University Press.

Melnik V. I. 2009. The species of the genus Botrychium Sw. (Botrychiaceae), recommended for inclusion in Red Data Book of Ukraine: geographical distribution and modern state of populations. Scientific reports of NUKMA 93: 45-53.

Meusel H., Jäger E. \& Weinert E. 1965. Vergleichende Chorologie der zentraleuropäischen Flora. I. Text 583 pp., Karten 258 pp. Gustav Fischer Verlag, Jena.

Mosyakin S. L. \& Fedoronchuk M. M. 1999. Vascular plants of Ukraine a nomenclatural checklist. 346 pp. M. G. Kholodny of Botany, National Academy of Sciences of Ukraine.

Oklejewicz K., Wolanin M. \& Wolanin M. N. 2015. Czerwona Księga Roślin Województwa Podkarpackiego. Zagrożone Gatunki Roślin, pp. 11-179. Stowarzyszenie na Rzecz Rozwoju i Promocji Podkarpacia "Pro Carpathia", Rzeszów.

Parfienov V. I. (ed.). 2009. Flora Belarusi. Sosudistye rasteniya, 1, 264 pp. Belaruskaya Nauka, Minsk.

PARNIKOZA I. Yu. 2002. A finding of Botrychium matricariifolium in the Middle Dnipro Region. Ukr. Bot. J. 59(6): 728-729.

PARnikoza I. 2010. Modern state of Ophioglossaceae populations of Ukraine flora. Nature Protected areas creation in Ukraine 16(1): 22-27.

Parnikoza I. Yu. \& Tsukanova G. A. 2005. Condition of the Botrychium multifidum (S. G. Gmel.) Rupr. cenopopulations in the Kyiv territory. Ukr. Bot. J. 62(2): 289-295.

Votkalchuk K. A., Sanislo Ya. P. \& Bezsmertna O. O. 2014. Distribution of Botrychium matricariifolium (Ophioglossaceae) in Ukraine. Ukr. Bot. J. 71(6): 723-727.

Parnikoza I. \& Celka Z. 2016. An archive of the Ophioglossaceae findings in Ukraine. In: Rare plants and fungi of Ukraine and adjacent areas: implementing 
conservation strategies. Proceedings of the 4rd International conference. Kyiv. 16-20 May 2016, pp. 119-125.

Paszkov G. P., Kaleda L. V., Logvin V. N. \& Petrikov A. M. 2005. Krasnaja kniga Respubliki Belaruc'. Rasteniya. 460 pp. Izdatel'stvo Belaruskaya Éncyklapedyya im. Petrucya Brovki, Minsk.

RašomaViČıUS V. (ed.). 2007. Red data book of Lithuania. 799 pp. Lututé, Publishing Company.

Regulation 2014. Regulation of Minister of Environment of 9 October 2014 on plant species protection. Journal of Laws 2014 item 1409.

Travlieiev A. P. (ed.). 2010. Chervona kniga Dnipropetrovski oblasti (Roslinni svit). 499 pp. Dnipropetrovsk.

Tzvelov N. N. 2000. Manual of the vascular plants of north-wets Russia (Leningrad, Pskov and Novgorod provinces). 781 pp. St.-Petersburg State ChemicalPharmaceutical Academy Press.

Valentine D. H. \& Moore D. M. 2007. Ophioglossaceae. In: T. G. Tutin, N. A. Burges, A. O. Chater, J. R. Edmondson, V. H. Heywood, D. M. Moore, D. H. Valentine, S. M. Walters \& D. A. WebB (eds.). Flora Europaea, 1 (Psilotaceae to Platanaceae), pp. 8-9. Cambridge, Cambridge University Press.

Vasheka O. V. \& Bezsmertna O. O. 2012. Ferns Atlas of Ukrainian Flora. 161 pp. Palyvoda, Kyiv.

Vetkin Yu. E., Geltman D. V., Litvinov E. M., Konechnaya G. Yu. \& Mishchenko A. L. 2015. Krasnaya kniga
Novgorodskoĭ oblasti. 479 pp. Izdatel`stvo Diton, Sankt-Petersburg.

Wagner W. H. JR. \& Wagner F. S. 1993. Ophioglossaceae C. Agardh. Adder's-tongue Family. In: FNA ED. Comm. (eds.). Flora of North America, 2: 85-106. Oxford University Press, New York-Oxford.

ZAJĄC M. \& ZAJĄC A. 2009. The geographical elements of native flora of Poland. 94 pp. Edited by Laboratory of Computer Chorology, Institute of Botany, Jagiellonian University, Kraków.

ZARZYCKI K. \& SZELĄG Z. 2006. Red list of the vascular plants in Poland. In: Z. MireK, K. ZARZycki, W. WojewodA \& Z. SzeląG (eds.). Red list of plants and fungi in Poland, pp. 9-20. W. Szafer Institute of Botany, Polish Academy of Sciences, Kraków.

Żukowski W. 2004. Botrychium simplex E. Hitchc. Podejźrzon pojedynczy In: A. Werblan \& B. SudniK-WójciKowsKA (eds.). Poradniki ochrony siedlisk i gatunków Natura 2000 - podręcznik metodyczny 9: 52-54.

Żukowski W., Celka Z. \& Olejnik N. 2014. EX Botrychium simplex E. Hitchc. Podejźrzon pojedynczy. In: R. Kaźmierczakowa, K. Zarzycki \& Z. Mirek (eds.). Polish Red Data Book of Plants. Pteridophytes and flowering plants, wyd. III uaktualnione i rozszerzone, pp. 41-42. Polska Akademia Nauk, Instytut Ochrony Przyrody, Kraków. 